\title{
Determination of the rolling resistance coefficient of pneumatic wheel systems
}

\author{
JEL: L62 DOI: 10.24136/atest.2019.066 \\ Data zgłoszenia: 15.12.2018 Data akceptacji: 08.02.2019
}

The basic resistance during moving objects that are equipped with a circular system is rolling resistance. In objects powered by muscle power, such as: bicycles, wheelchairs, mobile machines, shelves and storage trolleys, the problem of rolling resistance limitation is more important than in the case of structures powered by engines characterized by a significant excess of driving force relative to the sum of resistance forces. Research is being carried out on limiting the rolling resistance force, however, there is a lack of methods for measuring this parameter in the actual operating conditions of devices with a drive system without a drive unit. In the article for research, an innovative method was used of measuring the rolling resistance coefficient of objects equipped only with the rolling chassis of accordance with the patent application P.424484 and a test device compatible with the patent application P.424483. The study involved a pneumatic wheel commonly used in wheelchairs, the use of which gains popularity with increased interest in the construction of electric or diesel vehicles with low energy demand. Examples of such vehicles are available during the Shell Eco-marathon competition. The study was financed from the means of the National Centre for Research and Development under LIDER VII programme, research project no. LIDER/7/0025/L-7/15/NCBR/2016.

Słowa kluczowe: pneumatic wheel systems, rolling resistance coefficient, non-road vehicles.

\section{Introduction}

Lowering the rolling resistance is beneficial for all kinds of vehicles. By decreasing this parameter vehicles that are driven manually, electrically or by combustion engines increase the distance they can cover. Additionally, in case of disabled people the summation of all resistances while exploiting a wheelchair with a manual drive influences whether this person will be able to use this kind of vehicle independently. In case of vehicles propelled with combustion engines decreasing the rolling resistance coefficient has a positive impact on the environment by lowering the emission of exhaust gases or using the unrenewable sources of energy. In vehicles equipped with pneumatic tires the value of the rolling resistance coefficient changes alongside with:

- increasing the speed, increasing the tire deflection, result of which is a change of pressure in the wheel,

- increased transmission of a high torque because then peripheral deflections increase,

- lower tire thread height during change of load $[2,4,7,9-10,12$, 14, 16-17, 22, 30].

The problem of improper exploitation of vehicles with a low tire pressure was noticed by the automotive industry by introducing in Europe in 2014 a directive enforcing control and indication of tire pressure in newly produced vehicles [11]. The research on the rolling resistance coefficient available in literature mainly concern car tires $[2,4,7,9-10,12-14,16-17,21-22,30]$ and road surfaces $[2-3,7-10,12-13,15,30]$. The article the research results on the rolling resistance coefficient of pneumatic wheels used in wheelchairs (fig. 1) [19] or in vehicles taking part in ecological car races i.e. Shell Eco-marathon (fig. 2) [1, 3, 5, 18, 20, 23, 31].

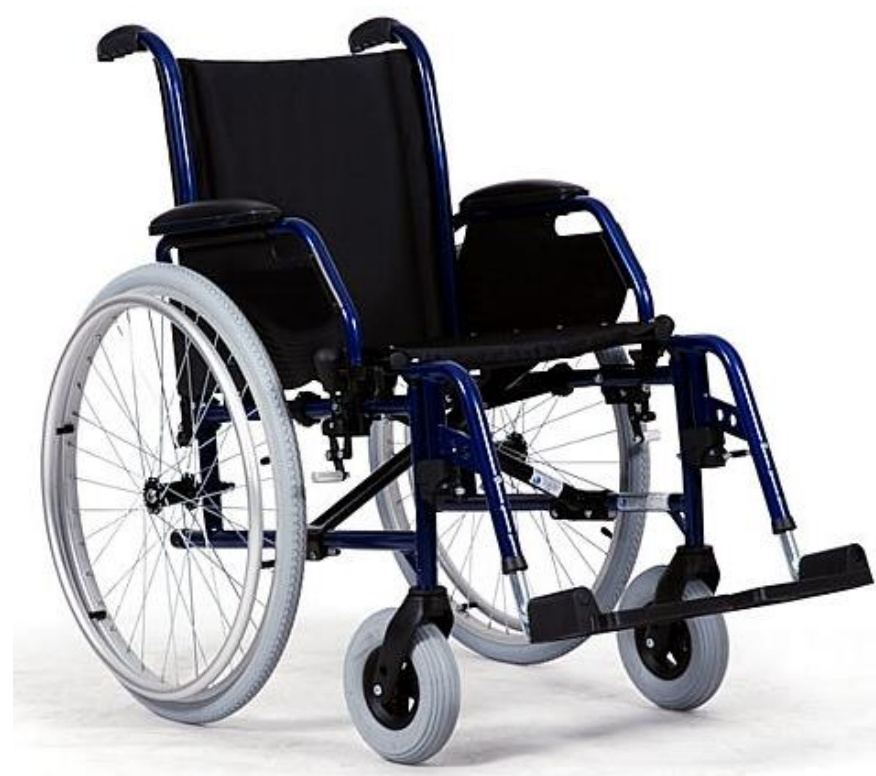

Fig. 1. A wheelchair

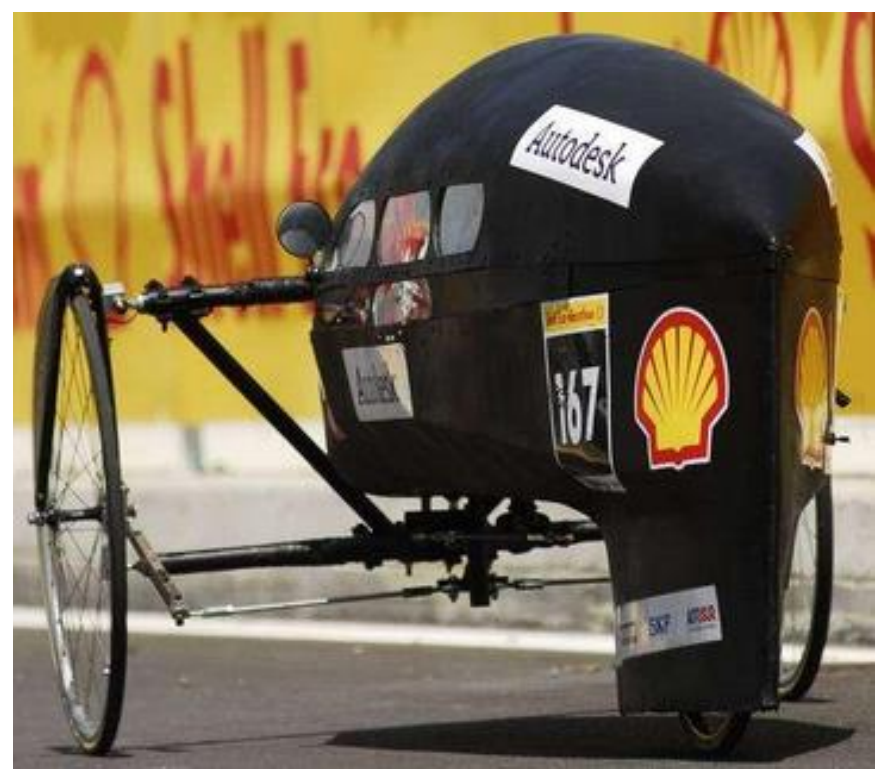

Fig. 2. A vehicle from Shell Eco-marathon [32]

1.Research object and research methodology

Research was carried out on a trolley equipped with four pneumatic wheels used i.e. in wheelchairs (fig. 3). The weight of the trolley necessary for determining the rolling resistance coefficient and the value of the system load is shown in table 1 . The tests were performed on a prototype research stand prepared in accordance with the patent application P.424484 [26] concerning the methodol- 
ogy of the measurement of rolling resistance coefficient of objects equipped only with the rolling chassis and with the use of a test device compatible with the patent application P.424483 [27]. Research method allows to determine the rolling resistance coefficient by the measurement of the rolling forces combining the features of road testing with stand testing. The core of the method of determining the rolling resistance coefficient of objects equipped with the rolling chassis is the fact, that the research object moves at a constant speed that allows to exclude the influence of the inertial forces on the system and on the rolling forces. Research methodology and a test device is described in literature by Warguła and team [24]. Research stand is presented in figure 4 that shows a research trolley with non-pneumatic wheels (front wheels of a wheelchair), trolley construction allows to change the wheels.

Tab. 1. Weight of research objects

\begin{tabular}{|l|c|}
\hline \hline \multicolumn{1}{|c|}{ Research objects: } & Weight: \\
\hline Weights & $75 \mathrm{~kg}$ \\
\hline Trolley frame & $15 \mathrm{~kg}$ \\
\hline Pneumatic wheels & $10 \mathrm{~kg}$ \\
\hline
\end{tabular}

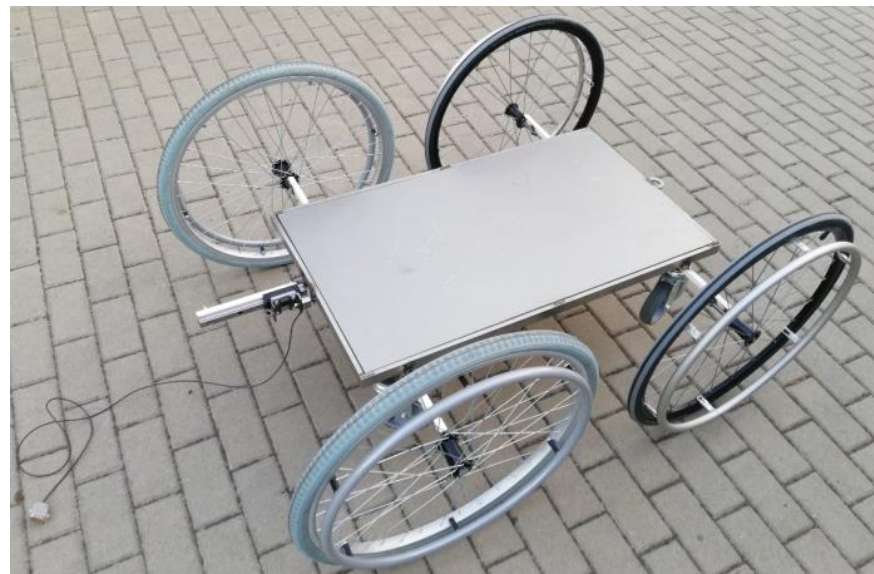

Fig. 3. Research trolley with pneumatic wheels used in wheelchairs

\section{Research results}

The results of force measurements with the use of described re- search methodology is shown in figure 5 indicating the characteristics of force measurement since the beginning of the movement till the research object is stopped. The characteristics showing the value of forces while moving at a constant speed is presented in figure 6 . The research results of the average value of force necessary for object to move at a constant speed with variable load is shown in table 2.

Tab. 2. Average value of force when towing the trolley within the range of stable movement depending on the weight of the trolley

\begin{tabular}{|c|c|c|c|c|}
\hline \multirow{3}{*}{ No } & \multicolumn{4}{|c|}{ Pressure in wheels } \\
\hline & \multicolumn{2}{|c|}{1,5 bar } & \multicolumn{2}{|c|}{2,5 bar } \\
\hline & $\mathrm{F}[\mathrm{N}]$ & $\mathrm{SD}^{*}$ & $\mathrm{~F}[\mathrm{~N}]$ & $S D^{*}$ \\
\hline 1. & 9,7 & 0,8 & 9,4 & 0,7 \\
\hline 2. & 10,8 & 0,9 & 9,8 & 0,9 \\
\hline 3. & 9,5 & 1,2 & 9,5 & 0,5 \\
\hline 4. & 10,9 & 1,5 & 9,9 & 0,8 \\
\hline 5. & 9,5 & 0,7 & 8,9 & 0,8 \\
\hline 6. & 9,4 & 1,0 & 10,1 & 0,7 \\
\hline 7. & 9,3 & 1,4 & 10,2 & 1,2 \\
\hline 8. & 9,7 & 1,5 & 9,4 & 0,9 \\
\hline 9. & 10,0 & 1,7 & 9,3 & 1,0 \\
\hline \multirow[t]{3}{*}{10.} & 9,4 & 1,3 & 9,8 & 0,7 \\
\hline & $\mathrm{F}[\mathrm{N}]$ & $\mathrm{SD}^{* *}$ & $\mathrm{~F}[\mathrm{~N}]$ & $\mathrm{SD}^{* *}$ \\
\hline & 9,8 & 0,55 & 9,6 & 0,38 \\
\hline \multicolumn{5}{|c|}{$\begin{array}{l}\mathrm{F} \text { - average force }[\mathrm{N}] \\
S D^{*} \text { - standard deviation for the mean, } \\
S D^{* *} \text { - standard deviation for a single measurement. }\end{array}$} \\
\hline
\end{tabular}

\section{Results analysis}

The developed method and stand allowed to determine the rolling resistance coefficient for the researched pneumatic wheels on a hard surface of ceramic tiles with variable pressure in wheels. The determined values are presented in table 3 . The change of wheel pressure from value of 2,5 bar to 1,5 bar did not influence significantly on the value of the rolling resistance coefficient. The value of the rolling resistance coefficient for one wheel equals about 0,0025 . A wheelchair with two pneumatic and two nonpneumatic wheels with a load of about $100 \mathrm{~kg}$ and wheel pressure 1,5 bar is characterized by a value of rolling resistance coefficient from 0,021 to 0,016 . Whereas the value of rolling resistance coeffi-

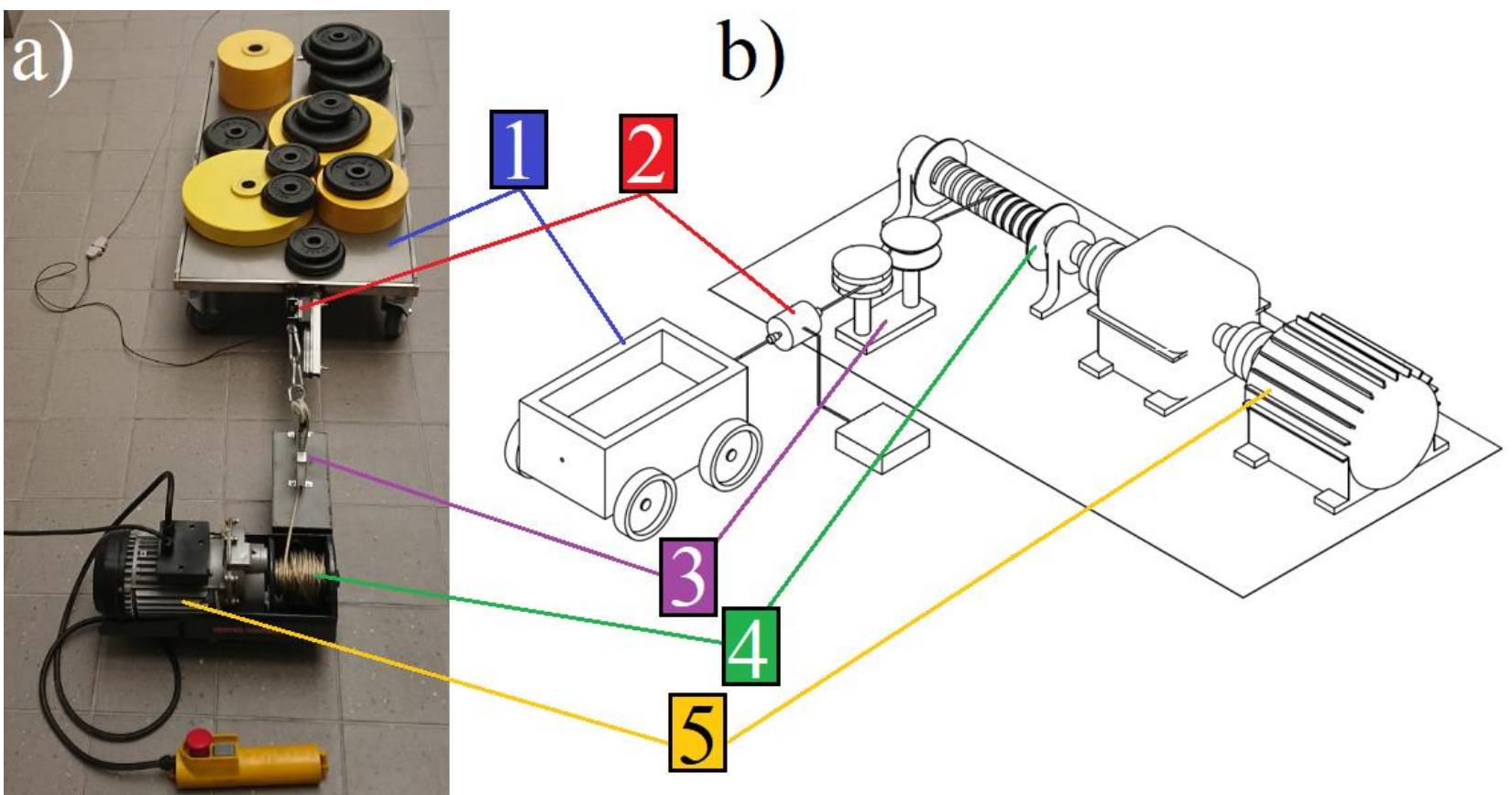

Fig. 4. Stand for determination of rolling resistance coefficients; a) prototype, b) concept drawing [27], where: 1 - tested object, 2 - force sensor, 3 - rope tension regulating system, 4 - rope winding system, 5 - drive unit [24] 
cient for non - pneumatic wheels equals about 0,0086 [24]. Analyzing the results of rolling resistance coefficients of wheelchairs and wheels applied in them in accordance with equation 1 the research results are correct.

$$
f_{c}=n_{n} \cdot f_{n}+n_{p} \cdot f_{p}
$$

where:

$f_{c}$ - total rolling resistance coefficient of a vehicle,

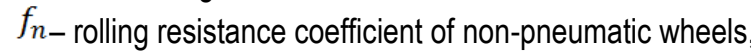

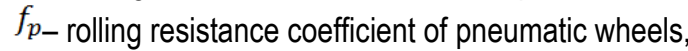

$n_{n-\text { number of non-pneumatic wheels in vehicle, }}$

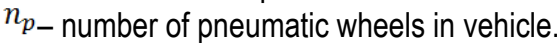

Tab. 3. The values of rolling resistance coefficients of trolley with pneumatic wheels

\begin{tabular}{|c|c|}
\hline \hline $\begin{array}{c}\text { The average value of rolling resistance coefficient determined on the basis of rolling } \\
\text { force }\end{array}$ \\
\hline $1,5 \mathrm{bar}$ & $2,5 \mathrm{bar}$ \\
\hline 0,01 & 0,01 \\
\hline
\end{tabular}

\section{Conclusions}

The values of the rolling resistance coefficients are in accordance with the data available in literature on pneumatic tires. It implicates that this method can be applied to continue research to determine the value of the rolling resistance coefficient of wheeled systems. Subsequent research will be carried out in order to determine the rolling resistance coefficient resulting from resistances of internal drive mechanisms of ecological vehicles and wheelchairs equipped with innovative drive systems i.e. lever drive system [28], multishift transmission [29] or hybrid electro-manual drive [25].
Bibliografia:

1. Andrzejewski P., Use of remote work tools in activities of vehicles designers scientific circle. Zeszyty Naukowe Wydziału Elektrotechniki i Automatyki PG, Nr 52/2017, p.11-14, ISSN 23531290

2. Dębicki M., Car theory. Drive theory (original title in Polish: Teoria samochodu. Teoria napędu) WNT, Warszawa1969.

3. Domek M., Opory ruchu pojazdu oraz minimalizacja oporów toczenia. Napędy i Sterowanie, R. 19, nr 12, p. 96-100, 2017

4. Grishkevich A.I., Automobiles, Theory (original title in Russian: Автомобили, Теория,) Издателъство Вышэишая Школа 1986.

5. Łach A., Wyleżoł M., Skarka W., Main aspects of modeling race car body designed for Shell Eco-marathon. Mechanik nr 2/2015 p. $148-151$

6. Merkisz J., Pielecha J., Stojecki A., Jasiński R., The influence of terrain topography on vehicle energy intensity and engine operating conditions, Combustion Engines, 162(3) p.341-349, 2015. ISSN 2300-9896

7. Minchejmer A., The theory of a moving car Państwowe Wydawnictwo Naukowe, Warszawa 1960.

8. Mitschke M., Dynamika samochodu. Wydawnictwa Komunikacji i Łaczności, Warszawa 1977.

9. Mitschke M., Car Dynamics. T. 1. Drive and braking WKŁ, Warszawa 1987.

10. Orzełowski S., Construction of chassis and car bodies (original title in Polish: Budowa podwozi i nadwozi samochodowych). WSiP, Warszawa 1996. ISBN 83-02-08785-8

11. Polasik J., Waluś K.J., The tire pressure monitoring system - an overview of solutions. Logistyka, nr 4, 5363-5367, CD 2, 2015.

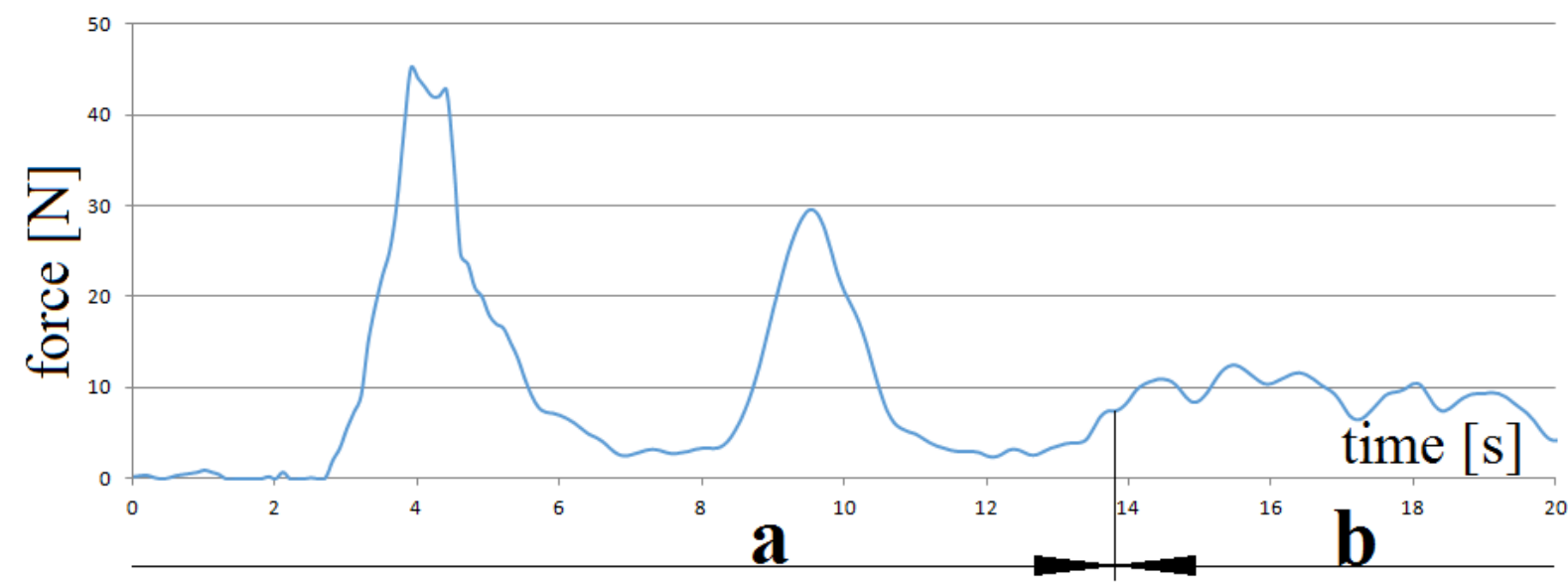

Fig. 5. Characteristic of change of force as a function of time when towing a trolley, where: $a$ - acceleration, $b$ - stabilization of movement

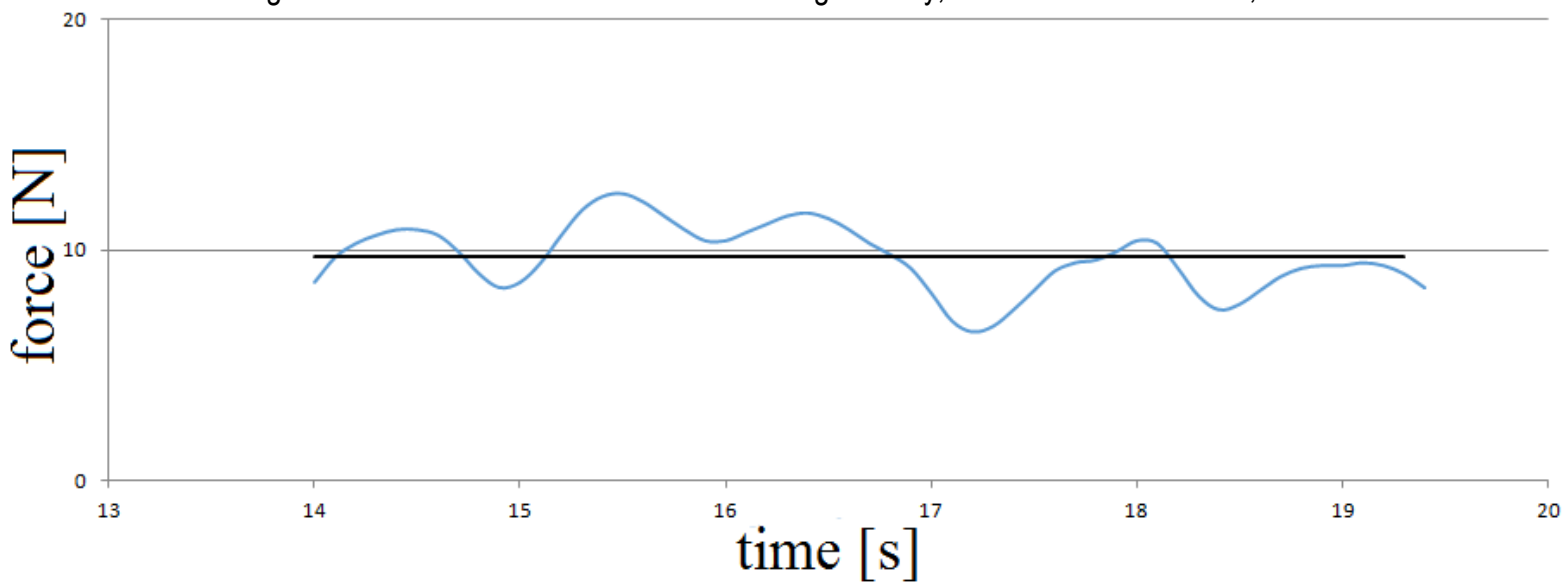

Fig. 6. The characteristics of changes in force as a function of time when towing a trolley within a range of stable movement where: blue line - force characteristic as a function of time, black line - average value of the rolling force 
12. Prochowski L., Car vehicles. Movement mechanics (original title in Polish: Pojazdy samochodowe. Mechanika ruchu), WKŁ, Warszawa 2008. ISBN 978-83-206-1701-6

13. Prochowski L., Unarski J., Wach W., Wicher J., Car vehicles. Basics of reconstruction of road accidents (original title in Polish: Pojazdy samochodowe. Podstawy rekonstrukcji wypadków drogowych) WKŁ, Warszawa 2008. ISBN 978-83-2061688-0

14. Reimpell J., Sponagel P. Chassis technology: tires and wheels (original title in German: Fahrwerktechnik: Reifen und Räder) Vogel Buchverlag, Würzburg 1988.

15. Sawicki P., Waluś K.J., Warguła Ł., The comparative analysis of the rolling resistance coefficients depending on the type of surface - experimental research. Transport Means 2018 : Proceedings of the 22nd International Scientific Conference, October 0305, 2018, Trakai, Lithuania. Part 1, p. 434 - 441

16. Siłka W., Theory of car motion, part II. Energy consumption of traffic and fuel consumption (original title in Polish: Teoria ruchu samochodu, cz. II. Energochłonność ruchu i zużycia paliwa) WSI, Opole 1994.

17. Siłka W. The theory of a moving car (original title in Polish: Teoria ruchu samochodu), Wydawnictwo Naukowo-Techniczne, Warszawa 2002. ISBN 83-204-2748-7

18. Skoberla R., Skarka W., Drive system of lightweight electric vehicle competing in Shell Eco-marathon. Mechanik nr 4/2016 p.324-325, DOI: 10.17814/mechanik.2016.4.47

19. Sydor M., Choosing and operating a wheelchair (original title in Polish: Wybór i eksploatacja wózka inwalidzkiego) Wydawnictwo Akademii Rolniczej im. Augusta Cieszkowskiego w Poznaniu, Poznań 2003. ISBN 83-7160-315-0

20. Targosz M., Cichoński K., Kotysz R., Gleń M., Szymon A., An experimental investigation of the energy consumption for lightweight electric vehicle. Zeszyty Naukowe Instytutu Pojazdów 3(99)/2014.

21. Taryma S., Opór toczenia opon samochodowych. Wydawnictwo Politechniki Gdańskiej, Gdańsk 2007.

22. Taryma S., Woźniak R., Passenger car tyres/road rolling resistance measurements on different surfaces. Archiwum Motoryzacji 2, p.1-10, 2006.

23. Tyczka M., Skarka W., Electric car with hydrogen fuel cell stack power supply. An alternative to battery power supply? Mechanik nr 3/2016 p. 238-239, DOI: 10.17814/mechanik.2016.3.32

24. Warguła $\measuredangle$., Wieczorek B., Kukla M., The determination of the rolling resistance coefficient of objects equipped with the wheels and suspension system - results of pilot tests. MATEC Web of Conferences (2019), MMS 2018, (in print)

25. Warguła Ł., Wieczorek B., Kukla M., patent application number P.427855, Zestaw modyfikacyjny układu napędu do hybrydowego elektryczno-ręcznego do wózka inwalidzkiego (2018.11.21)

26. Wieczorek B., Warguła Ł., Waluś K.J., Krawiec P., patent application number P.424484, The method of determining the rolling resistance coefficient of objects equipped with the wheels and suspension system. (original title in Polish: Sposób wyznaczania współczynnika oporów toczenia obiektów wyposażonych w układ jezdny) (2018.02.02)

27. Wieczorek B., Warguła Ł., Waluś K.J., Kukla M., patent application number P.424483, A device for measuring the rolling resistance of objects equipped with the wheels and suspension system. (original title in Polish: Urządzenie do pomiaru siły opo- rów toczenia obiektów wyposażonych w układ jezdny) (2018.02.02)

28. Wieczorek B., Zabłocki M., Dźwigniowy system napędowy wózka inwalidzkiego, patent number PL223141B1, date of patent application (07.07.2014)

29. Wieczorek B., Zabłocki M., Piasta przekładniowa wielobiegowa do ręcznych wózków inwalidzkich. patent number PL223142B1, date of patent application (07.07.2014)

30. Wierciński J., Reza A., Wypadki drogowe. Vademecum biegłego sądowego. Wydawnictwo Instytutu Ekspertyz Sądowych, Kraków 2002. ISBN 83-87425-65-6

31. Zadorożny T., Żymełka S., Holewiak F., Katunin A., Optimal materials selection for construction of ultra-lighweight racing vehicle. Modelowanie inżynierskie 43, p. 265-272, Gliwice 2012, ISSN 1896-771X

32. https://www.autocentrum.pl/publikacje/relacje/eko-maraton2007/

\section{Wyznaczanie współczynnika oporu toczenia pneumatycznych układów kołowych}

Podstawowym oporem podczas przemieszczania obiektów które są wyposażone w układ kołowy jest opór toczenia. W obiektach napędzanych siłą mięśni takich jak: rowery, wózki inwalidzkie, mobilne maszyn, regały i wózki magazynowe zagadnienie ograniczenia oporów toczenia jest zacznie bardziej istotniejsze niż w przypadku konstrukcji napędzanych silnikami charakteryzującymi się znaczna nadwyżka siły napędowej względem sumy sił oporów ruchu. Prowadzone są badania na ograniczaniem siły oporów toczenia jednak dostrzegany jest brak metod pomiaru tego parametru w rzeczywistych warunkach eksploatacji urządzeń z układem jezdnym bez jednostki napędowej. W artykule do badań zastosowano innowacyjną metodę pomiaru współczynnika oporów toczenia obiektów wyposażonych tylko w układ jezdny zgodny ze zgłoszeniem patentowym P.424484 oraz kompatybilne $z$ metoda urządzenie badawcze zgodne ze zgłoszeniem patentowym P.424483. Badaniu poddano pneumatycznego koła stosowane powszechnie w wózkach inwalidzkich, których zastosowanie zwiększa się wraz ze wzrostem zainteresowania budowa pojazdów elektrycznych lub spalinowych o małym zapotrzebowaniu energetycznym. Przykłady taki pojazdów są dostępne podczas zawodów Shell Eco-marathon. Badanie zostało sfinansowane ze środków Narodowego Centrum Badań i Rozwoju w ramach programu LIDER VII, projekt badawczy nr. LIDER / 7/0025 / L-7/15 / NCBR / 2016.

Keywords: pneumatyczne uklady kołowe, współczynnik oporów toczenia, pojazdy niedrogowe.

Autorzy:

dr inż. Łukasz Warguła - Poznan University of Technology, Faculty of Transport Engineering, Chair of Basic of Machine Design, Piotrowo street 3, 60-965 Poznań, Poland,

lukasz.wargula@put.poznan.pl

dr inż. Mateusz Kukla - Poznan University of Technology, Faculty of Transport Engineering, Chair of Basic of Machine Design, Piotrowo street 3, 60-965 Poznań, Poland,

Mateusz.kukla@put.poznan.pl

dr inż. Bartosz Wieczorek - Poznan University of Technology, Faculty of Transport Engineering, Chair of Basic of Machine Design, Piotrowo street 3, 60-965 Poznań, Poland,

bartosz.wieczorek@put.poznan.pl 